\title{
KELIMPAHAN FITOPLANKTON DAN PERANNYA SEBAGAI SUMBER MAKANAN IKAN DI TELUK PABEAN, JAWA BARAT
}

\author{
Abundance of Phytoplankton and its Role as Fish Food Sources in Pabean Bay, \\ West Java
}

\author{
Ayu Andriani ${ }^{1 *}$, Ario Damar ${ }^{2,3}$, MF Rahardjo ${ }^{2,4}$, Charles P. H. Simanjuntak ${ }^{2,4}$, Aries \\ Asriansyah $^{2}$, Reiza Maulana Aditriawan ${ }^{2}$ \\ ${ }^{1}$ Program Studi Manajemen Sumberdaya Perairan, FPIK, IPB, Bogor, 16680, Indonesia \\ ${ }^{2}$ Departemen Manajemen Sumberdaya Perairan, FPIK, IPB, 16680, Indonesia \\ ${ }^{3}$ Pusat Kajian Sumber Daya Pesisir dan Lautan (PKSPL), IPB, 16680, Indonesia \\ ${ }^{4}$ Masyarakat Iktiologi Indonesia (MII), Cibinong, 16911, Indonesia \\ *Korespondensi: ayumsp50@gmail.com
}

\begin{abstract}
ABSTRAK
Teluk Pabean merupakan perairan estuari yang memiliki sumber daya alam potensial bagi perikanan. Salah satu organisme yang memiliki peran penting dalam teluk tersebut adalah fitoplankton. Penelitian ini bertujuan untuk menganalisis kelimpahan fitoplankton secara spasial dan temporal sebagai sumber makanan ikan di perairan Teluk Pabean, Jawa Barat. Pengambilan contoh fitoplankton dan pengukuran beberapa parameter fisik-kimiawi perairan dilakukan satu kali pada setiap bulan (Juni 2016-Maret 2017). Analisis data yang dilakukan meliputi komposisi dan kelimpahan fitoplankton, analisis ragam satu arah berdasarkan waktu dan zona pengamatan, kaitan parameter fisik-kimiawi perairan terhadap kelimpahan fitoplankton di Teluk Pabean, serta fitoplankton yang dimanfaatkan oleh ikan sebagai makanannya di Teluk Pabean, Jawa Barat. Kelimpahan fitoplankton tidak berbeda pada setiap zona pengamatan, tetapi kelimpahan fitoplankton berbeda antarwaktu pengamatan. Fitoplankton yang ditemukan di Teluk Pabean didominasi oleh fitoplankton kelas Bacillariophyceae. Jenis fitoplankton yang dominan menjadi makanan beberapa ikan di Teluk Pabean Jawa Barat yaitu Nitzschia dan Pleurosigma dari kelas Bacillariophyceae.
\end{abstract}

Kata kunci: Fisik-kimiawi perairan, ikan, kelimpahan fitoplankton

\begin{abstract}
Pabean Bay is an estuary that has the potential natural resources for fisheries. One of the organisms that has an important role here is phytoplankton. This study aims to analyze spatially and temporally the composition of phytoplankton abundance as food source for fish in Pabean Bay waters, West Java. Samples of phytoplankton and physics-chemical parameters were taken monthly (June 2016-March 2017). Data analysis consisted of composition and abundance of phytoplankton, one-way variance analysis based on time and zone, the relation of water physics-chemical parameters to phytoplankton abundance, and phytoplankton used by fish as food. The abundance of phytoplankton differs on monthly basis, but not different in each observd zone. The phytoplankton found in the Pabean Bay is dominated by the Bacillariophyceae class. The dominant type of phytoplankton feeds from some of the captured fishes was Nitzschia and Pleurosigma of Bacillariophyceae class.
\end{abstract}

Key words: Abundance, fish, physics-chemical water 


\section{PENDAHULUAN}

Teluk Pabean merupakan perairan estuari yang terletak di Kecamatan Pasekan, Kabupaten Indramayu, Provinsi Jawa Barat. Teluk ini didominasi oleh kawasan hutan mangrove serta terdapat aliran muara Sungai Cimanuk yang berhadapan langsung dengan laut. Keadaan tersebut menjadikan Teluk Pabean sebagai sumber daya alam potensial bagi perikanan. Teluk ini dimanfaatkan oleh warga sekitar sebagai tempat budi daya dan area penangkapan ikan.

Salah satu organisme yang memiliki peran penting dalam teluk tersebut adalah fitoplankton. Organisme ini memiliki klorofil yang mampu mengubah bahan anorganik menjadi bahan organik melalui proses fotosintesis. Bahan organik dari fitoplankton tersebut dimanfaatkan oleh zooplankton, larva ikan, maupun organisme perairan lainnya sebagai sumber makanan. Fitoplankton mempunyai peran penting dalam rantai makanan di perairan. Hampir seluruh ikan pelagis kecil dan larvanya meman-faatkan plankton (fitoplankton atau zooplankton) sebagai makanannya (Nontji 2008). Fitoplankton berperan sebagai bahan makanan dasar utama dalam siklus makanan di dalam perairan (Davis 1955). Dengan demikian kelim-pahan fitoplankton penting bagi potensi makanan ikan di alam.

Ikan di perairan Baru Selat Makasar misalnya yang memanfaatkan fitoplank-ton yaitu ikan teri (Stolephorus spp.) dari famili Engraulidae (Simbolon $d k k$. 2010). Informasi mengenai kelimpahan fitoplankton sangat penting karena merupakan sumber makanan bagi ikan pada tingkat trofik yang rendah. Di

Teluk Pabean informasi tentang fitoplankton masih terbatas pada jenis dan keragamannya, sedangkan sejauh ini penelitian tentang fitoplankton yang dimanfaatkan oleh ikan di Teluk Pabean belum pernah dilakukan.

Penelitian ini bertujuan untuk mengana-lisis komposisi kelimpahan spasial dan temporal fitoplankton dan perannya se-bagai sumber makanan ikan di perairan Teluk Pabean, Jawa Barat. Hasil pene-litian ini dapat memberikan informasi mengenai komposisi, jenis, kelimpahan fitoplankton dan kaitannya dengan beberapa parameter fisikkimiawi perairan di Teluk Pabean, Jawa Barat. Selain itu, penelitian ini juga dapat memberikan informasi mengenai jenis fitoplankton yang banyak dimanfaatkan oleh ikan-ikan di perairan ini.

\section{METODE PENELITIAN}

Penelitian dilakukan pada bulan Juni 2016 sampai Maret 2017 di Teluk Pabean, Indramayu, Jawa Barat (Gambar 1). Pengambilan fitoplankton, dan pengukuran parameter fisik-kimiawi perairan dilakukan satu kali pada setiap bulan. Pengambilan contoh dilakukan pada tiga zona yaitu zona 1 , zona 2 , dan zona 3. Zona 1 berada di bagian dalam teluk dan dikelilingi oleh hutan mangrove. Zona 2 merupakan daerah yang berada di sekitaran muara Sungai Cimanuk. Zona 3 berada pada bagian luar teluk ke arah laut lepas. Analisis fitoplankton dilakukan di Laboratorium Biologi Makro 1, Departemen Manajemen Sumberdaya Perairan, Fakultas Perikanan dan Ilmu Kelautan, Institut Pertanian Bogor. 


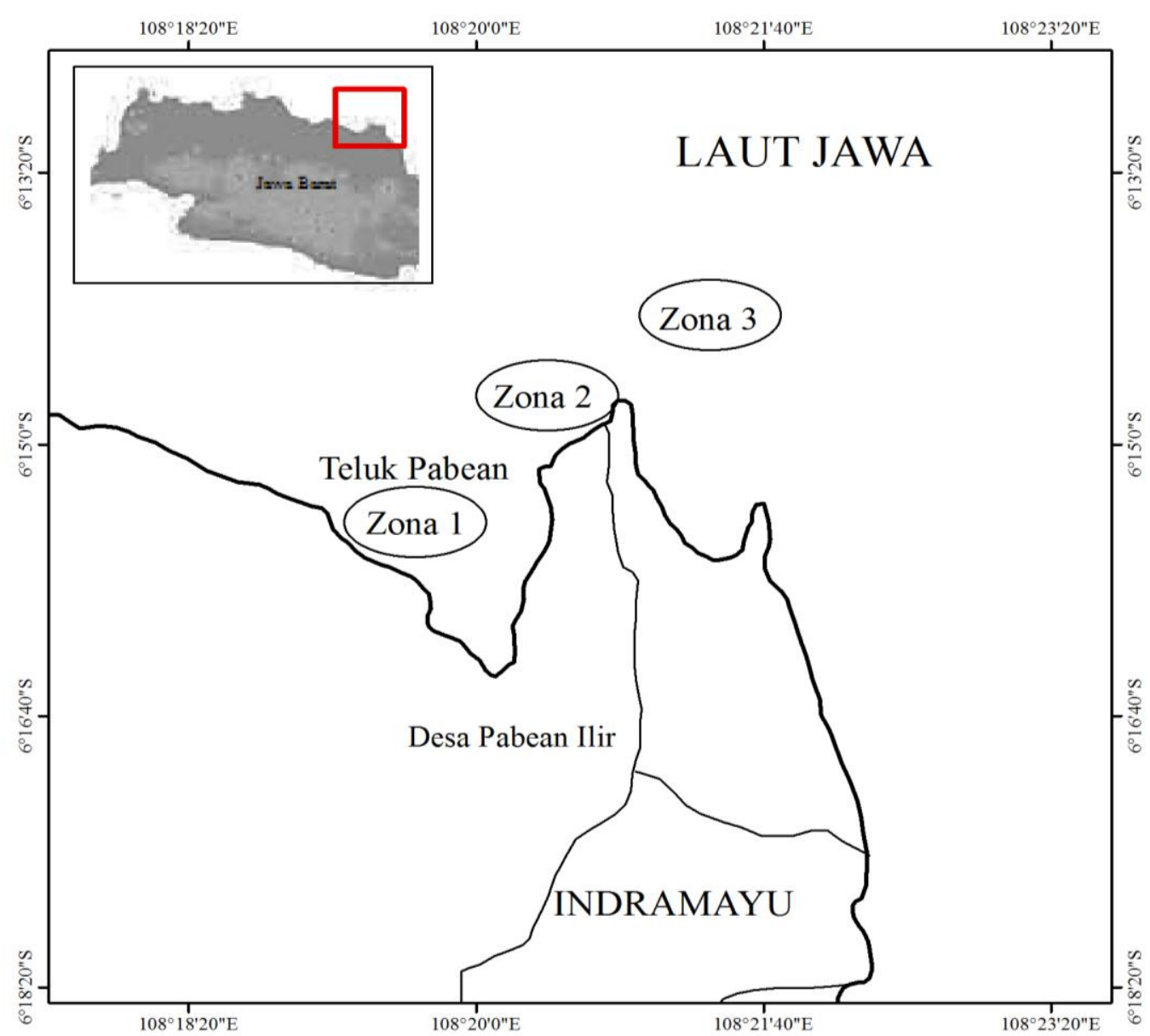

Gambar 1. Zona pengambilan contoh

Data yang dikumpulkan dalam penelitian ini berupa data primer dan data sekunder. Data primer diperoleh melalui hasil pengukuran dan pengamatan lapangan serta analisis di laboratorium. Pengumpulan data parameter fisikkimiawi perairan dilakukan in situ dan analisis laboratorium dengan me-tode serta alat ukur yang tersebut dalam Tabel 1. Fitoplankton diambil menggu-nakan plankton net dengan mata jaring 53 mikron, panjang $1,5 \mathrm{~m}$, dan diameter 40 $\mathrm{cm}$. Selain itu, plankton net juga dilengkapi dengan flow meter. Perputaran flow meter pada plankton net dicatat untuk pengukuran volume air yang tersaring. Plankton net dilengkapi dengan pemberat yang bertujuan untuk menenggelamkan plankton net ke dalam perairan, kemudian plankton net ditarik ke atas.

Identifikasi fitoplankton dilakukan secara sensus menggunakan mikroskop perbesaran 10×10, Sedgwick-Rafter Counting Cell (SRC) berukuran $50 \times 20 \times 1$ $\mathrm{mm}^{3}$, dengn mengacu pada buku identifikasi Yamaji (1979), serta Chihara \& Murano (1997). Kelimpahan fitoplankton dihitung menggunakan persamaan APHA 2012:

$$
\mathrm{N}=\mathrm{n} \times \frac{\mathrm{a}}{\mathrm{A}} \times \frac{\mathrm{v}}{\mathrm{Vc}} \times \frac{1}{\mathrm{~V}}
$$

Keterangan:

$\mathrm{N}=$ kelimpahan plankton $\left(\mathrm{sel} \mathrm{L}^{-1}\right)$

$\mathrm{n}=$ jumlah plankton yang tercacah (sel)

$\mathrm{a}=$ luas gelas penutup $\left(\mathrm{mm}^{2}\right)$

$\mathrm{v}=$ volume air terkonsentrasi $(\mathrm{ml})$

$\mathrm{A}=$ luas satu lapangan pandang $\left(\mathrm{mm}^{2}\right)$

$\mathrm{Vc}=$ volume air dibawah gelas penutup $(\mathrm{ml})$

$\mathrm{V}=$ volume air yang disaring $(\mathrm{L})$ 
Tabel 1. Parameter fisik-kimiawi yang diamati (APHA 2012)

\begin{tabular}{lcll}
\hline \multicolumn{1}{c}{ Parameter } & Satuan & & \multicolumn{1}{c}{ Metode/alat ukur } \\
\hline Kedalaman & $\mathrm{M}$ & Tali berskala \\
Suhu & ${ }^{\circ} \mathrm{C}$ & Termometer \\
Kecerahan & $\mathrm{Cm}$ & Visual/cakram Secchi \\
$\mathrm{pH}$ & - & $\mathrm{pH}$ meter \\
Salinitas & $\%$ & Elektrometrik/SCT (Salinity, Conductivity, \\
Oksigen terlarut & $\mathrm{mg} \mathrm{L}^{-1}$ & Temperature) \\
& & DO meter \\
\hline
\end{tabular}

Data yang digunakan dalam analisis ini berupa data kelimpahan fitoplankton, dan parameter fisik-kimiawi perairan. Analisis ragam satu arah berdasarkan zona dan waktu pengamatan dilakukan menggunakan bantuan perangkat lunak SPSS Versi 20. Analisis tersebut dila-kukan untuk menganalisis pengaruh zona dan waktu terhadap kelimpahan fitoplankton dan parameter fisik-kimiawi perairan. Kaitan kelimpahan fitoplankton dengan beberapa parameter fisik-kimiawi perairan dianalisis menggunakan Analisis Korespondans Kanonik dengan bantuan perangkat lunak Past3.

Jenis fitoplankton yang dimanfaatkan oleh ikan di Teluk Pabean dapat diketahui dengan menggunakan data kelimpahan fitoplankton dan data makanan dari jenis-jenis ikan yang tertangkap di teluk tersebut. Analisis ini dilakukan untuk menentukan jenis fitoplankton yang dimakan oleh ikan, serta jenis fitoplankton yang tidak dimakan oleh ikan di Teluk Pabean.

\section{HASIL}

\section{Komposisi fitoplankton di Teluk Pabean}

Fitoplankton yang ditemukan di Teluk Pabean terdiri atas 29 genera. Komposisi fitoplankton yang ditemukan di Teluk Pabean disajikan dalam Tabel 2.

Tabel 2. Komposisi fitoplankton di Teluk Pabean

\begin{tabular}{|c|c|}
\hline Kelas & Genera \\
\hline Bacillariophyceae & $\begin{array}{l}\text { Amphiprora, Bacteriastrum, Biddulphia, Cerataulina, Chaetoceros, } \\
\text { Coscinodiscus, Detonula, Ditylum, Eucampia, Ethmodiscus, Guinardia, } \\
\text { Gyrosigma, Hemiaulus, Melosira, Nitzschia, Pleurosigma, Rhabdonema, } \\
\text { Rhizosolenia, Skeletonema, Streptotheca, Surirella, Thalassionema, } \\
\text { Thalassiothrix, Thalassiosira }\end{array}$ \\
\hline Dinophyceae & Ceratium, Dinophysis, \\
\hline Cyanophyceae & Trichodesmium \\
\hline Chrysophyceae & Dictyocha \\
\hline
\end{tabular}

\section{Kelimpahan fitoplankton di Teluk Pabean}

Fitoplankton yang ditemukan selama sepuluh bulan pengamatan disajikan pada Gambar 2. Fitoplankton kelas Bacillariophyceae merupakan fitoplankton yang mendominasi di perairan Teluk Pabean.
Kelimpahan rata-rata fitoplankton pada setiap zona disajikan pada Gambar 3. Fitoplankton kelas Bacillariophyceae paling banyak ditemukan pad ketiga zona, sedangkan fitoplankton kelas Chrysophyceae merupakan fitoplankton yang paling jarang ditemukan pada ketiga zona pengamatan.

Rata-rata kelimpahan fitoplankton tertinggi ditemukan pada zona 2 yang 
yaitu dengan nilai rata-rata kelimpahan 884 sel L $^{-1}$ dan terendah pada zona 3 dengan rata-rata kelimpahan $459 \mathrm{sel} \mathrm{L}^{-1}$ (Gambar 4). Rata-rata kelimpahan fitoplankton pada zona 1 yaitu diperoleh nilai sebesar 870 sel $L^{-1}$. Nilai kelimpahan zona 1 dan zona 2 tidak jauh berbeda, yakni hanya selisih $14 \mathrm{sel} \mathrm{L}^{-1}$. Berdasarkan analisis ragam, kelimpahan fitoplankton kelas Bacillariophyceae, Dinophyceae, Cyanophyceae dan Chrysophyceae pada setiap zona memiliki nilai $\operatorname{Sig}>0,05$. Zona 2 yang memiliki kelimpahan fitoplankton paling tinggi merupakan zona yang terdapat aliran muara sungai Cimanuk.

Berdasarkan analisis ragam, kelimpahan fitoplankton kelas Bacillariophyceae dan Dinophyceae serta kelimpahan fitoplankton secara keseluruhan berbeda pada setiap waktu pengamatan karena nilai $\operatorname{Sig}<0,05$ ), tetapi waktu pengamatan tidak berpengaruh terhadap kelimpahan fitoplankton kelas Cyanophyceae dan Chrysophyceae karena nilai Sig>0,05. Rata-rata kelimpahan fitoplankton pada setiap zona sangat berfluktuasi (Gambar 5). Zona 1 dan 2 memiliki rata-rata kelimpahan fitoplankton tertinggi pada bulan November 2016 dengan nilai kelimpahan 2014 sel L$^{-1}$ pada zona 1 dan 3272 sel $\mathrm{L}^{-1}$ pada zona 2. Zona 3 memiliki nilai rata-rata kelimpahan fitoplankton tertinggi pada bulan Juni 2016 dengan nilai kelimpahan 1033 sel $\mathrm{L}^{-1}$.

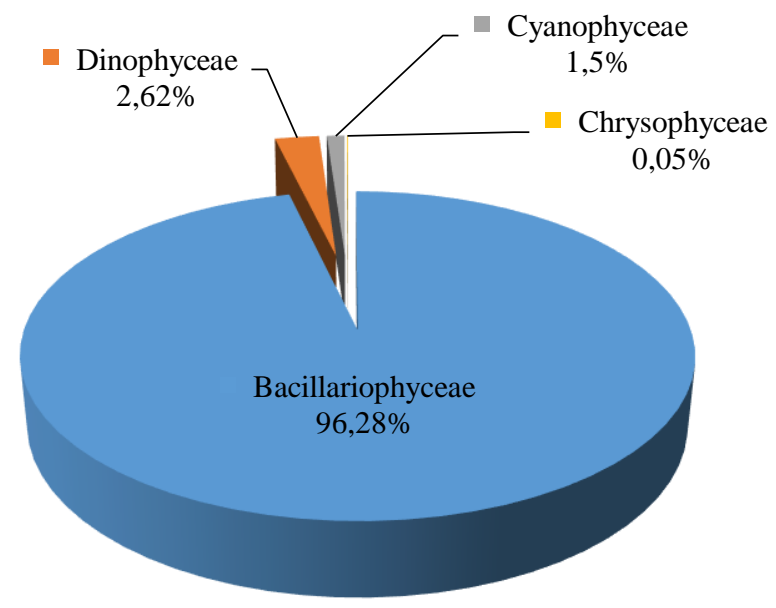

Gambar 2. Kelimpahan rata-rata fitoplankton di perairan Teluk Pabean

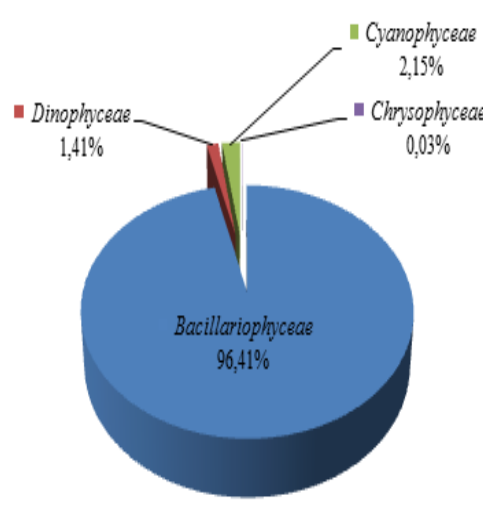

Zona 1

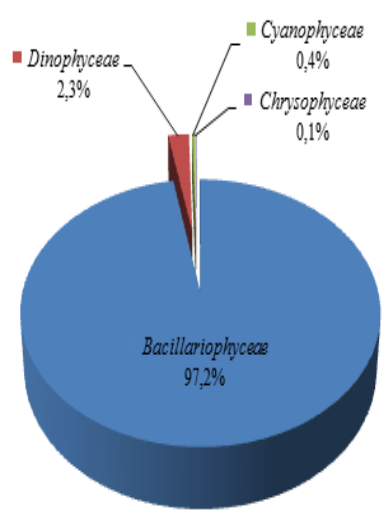

Zona 2

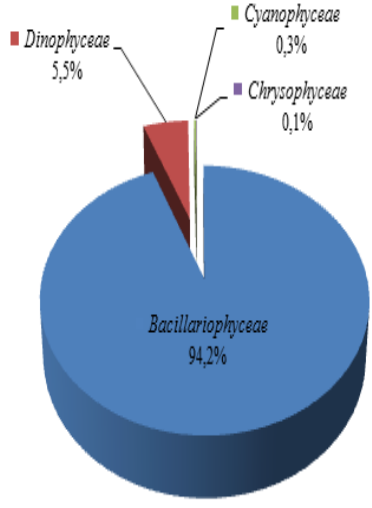

Lona 3

Gambar 3. Kelimpahan rata-rata fitoplankton pada setiap zona 


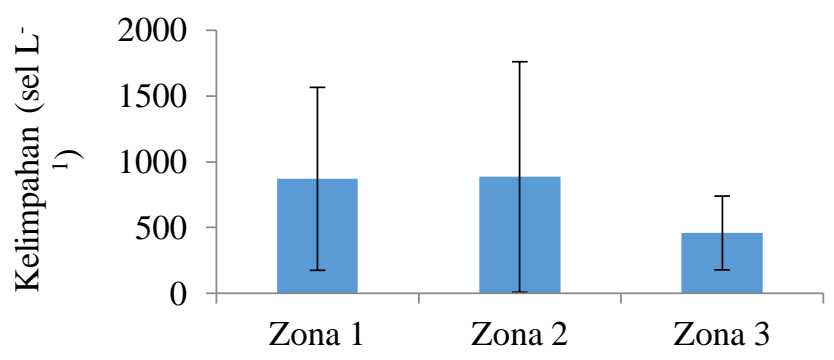

Gambar 4. Rata-rata kelimpahan fitoplankton selama pengamatan bulan Juni 2016-Maret 2017 pada setiap zona (Keterangan = simpangan baku)
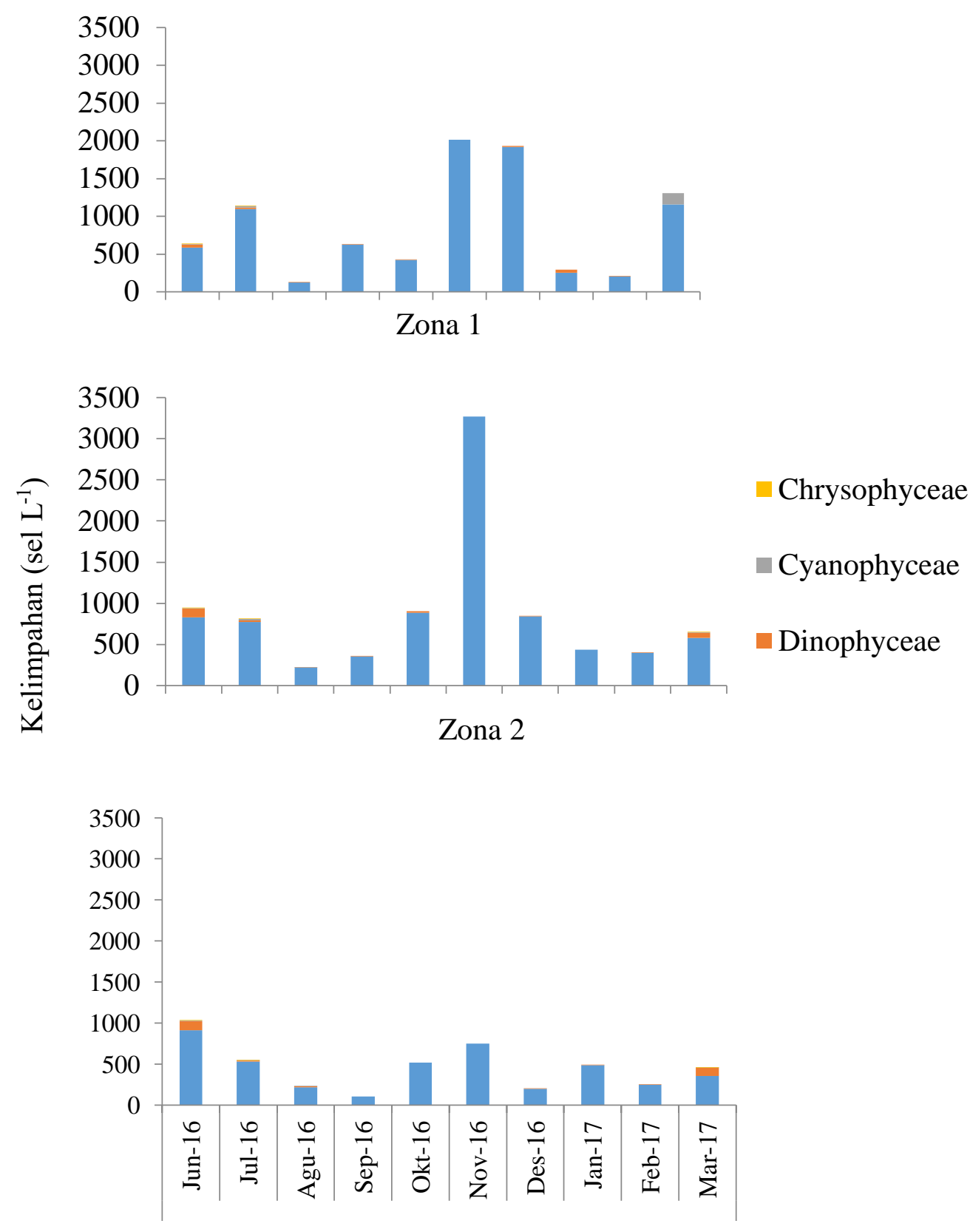

Gambar 5. Kelimpahan fitoplankton tiap bulan pada tiap zona di Teluk Pabean 
Kaitan kelimpahan fitoplankton dengan parameter fisik-kimiawi perairan

Nilai parameter fisik-kimiawi perairan di Teluk Pabean disajikan pada Tabel 3. Berdasarkan analisis ragam pada kedalaman, kecerahan, suhu, oksigen terlarut, salinitas, dan pH tidak memiliki pengaruh yang signifikan $(\mathrm{Sig}>0,05)$ terhadap ketiga zona.

Tabel 3. Parameter fisik-kimiawi perairan di Teluk Pabean

\begin{tabular}{lcccccc}
\hline Bulan & $\begin{array}{c}\text { Kedalaman } \\
(\mathrm{m})\end{array}$ & $\begin{array}{c}\text { Kecerahan } \\
(\mathrm{m})\end{array}$ & $\begin{array}{c}\text { Suhu } \\
\left({ }^{\circ} \mathrm{C}\right)\end{array}$ & $\begin{array}{c}\text { Oksigen } \\
\text { Terlarut } \\
\left(\mathrm{mg} \mathrm{L}^{-1}\right)\end{array}$ & $\begin{array}{c}\text { Salinitas } \\
(\mathrm{ppt})\end{array}$ & $\mathrm{pH}$ \\
\hline Juni & 1,10 & 0,48 & 30 & 7 & 31 & 7 \\
Juli & 2,07 & 0,67 & 29 & 5 & 30 & 7 \\
Agustus & 1,27 & 0,30 & 31 & 7 & 31 & 7 \\
September & 1,54 & 0,71 & 30 & 7 & 34 & 8 \\
Oktober & 0,74 & 0,24 & 27 & 7 & 31 & 7 \\
November & 1,37 & 0,78 & 31 & 8 & 31 & 8 \\
Desember & 0,55 & 0,23 & 30 & 6 & 29 & 8 \\
Januari & 0,59 & 0,30 & 29 & 7 & 25 & 8 \\
Februari & 1,57 & 0,67 & 31 & 6 & 33 & 7 \\
Maret & 1,89 & 0,49 & 22 & 7 & 30 & 8 \\
\hline
\end{tabular}

Hubungan antara parameter fisikkimiawi perairan terhadap kelimpahan fitoplankton pada setiap zona dapat dilihat pada Gambar 6. Sumbu pertama atau Axis 1 dengan Eigenvalue $=0,013$ memodelkan $84 \%$ varian total yang dijelaskan, sumbu ke dua atau Axis 2 dengan Eigenvalue $=0,024$ mewakili $15 \%$ varian yang dijelaskan, dan sumbu ketiga atau Axis 3 dengan Eigenvalue = 0,001 mewakili $1 \%$ varian yang dijelaskan.

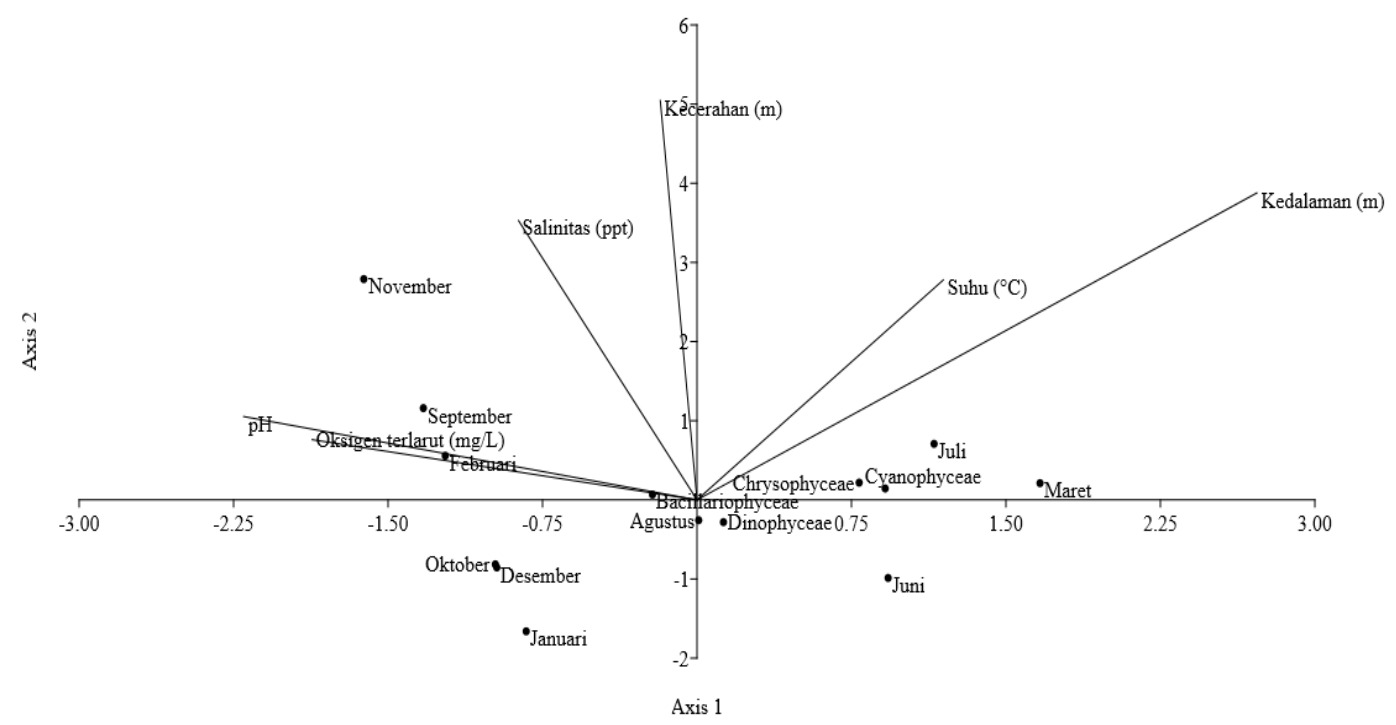

Gambar 6. Hubungan fitoplankton dengan parameter fisik-kimiawi perairan pada setiap bulan di Teluk Pabean 
Peran fitoplankton sebagai makanan ikan di Teluk Pabean

Ikan yang tertangkap di Teluk Pabean dan memakan fitoplankton diantarannya yaitu ikan famili Mugilidae (Chelon subviridis dan Moolgarda engeli), famili Engraulidae (Thryssa mystax, Stolephorus indicus, dan Thryssa hamiltonii), famili Clupeidae (Sardinella gibbosa, Anadontostoma chacunda, dan Sardinella fimbriata), serta famili Gobiidae (Parapocryptes serperaster).
Jenis fitoplankton yang dominan menjadi makanan beberapa ikan tersebut yakni Nitzschia dan Pleurosigma dari kelas Bacillario-phyceae (Tabel 4). Fitoplankton yang tidak dimakan oleh sembilan jenis ikan ada 13 genera yaitu 12 genera dari kelas Bacillariophyceae (Amphiprora, Bacteriastrum, Cerataulina, Eucampia, Ethmodiscus, Guinardia, Skeletonema, Streptotheca, Thalassionema, Thalassiosira, dan Ceratium) dan satu genera dari kelas Chrysophyceae (Dictyocha).

Tabel 4. Fitoplankton sebagai makanan ikan di Teluk Pabean

\begin{tabular}{|c|c|c|c|c|c|c|c|c|c|c|c|}
\hline \multicolumn{2}{|l|}{ Organisme } & \multicolumn{9}{|c|}{ Ikan } & \multirow{2}{*}{$\Sigma$} \\
\hline Kelas & Genera & 1 & 2 & 3 & 4 & 5 & 6 & 7 & 8 & 9 & \\
\hline \multirow{25}{*}{ Bacillariophyceae } & Amphiprora & & & & & & & & & & - \\
\hline & Bacteriastrum & & & & & & & & & & - \\
\hline & Biddulphia & $\sqrt{ }$ & $\sqrt{ }$ & & & & & & & & 2 \\
\hline & Cerataulina & & & & & & & & & & - \\
\hline & Chaetoceros & $\sqrt{ }$ & $\sqrt{ }$ & & & & & & & & 3 \\
\hline & Coscinodiscus & $\sqrt{ }$ & $\sqrt{ }$ & & & & $\sqrt{ }$ & $\sqrt{ }$ & $\sqrt{ }$ & $\sqrt{ }$ & 7 \\
\hline & Detonula & & & & & & & & & $\sqrt{ }$ & 1 \\
\hline & Ditylum & & & & & & $\sqrt{ }$ & & & & 1 \\
\hline & Eucampia & & & & & & & & & & - \\
\hline & Ethmodiscus & & & & & & & & & & - \\
\hline & Guinardia & & & & & & & & & & - \\
\hline & Gyrosigma & $\sqrt{ }$ & $\sqrt{ }$ & & & & & & & $\sqrt{ }$ & 4 \\
\hline & Hemiaulus & $\sqrt{ }$ & $\sqrt{ }$ & & & & & & & & 3 \\
\hline & Melosira & & & & & & & & & $\sqrt{ }$ & 1 \\
\hline & Nitzschia & $\sqrt{ }$ & $\sqrt{ }$ & $\sqrt{ }$ & & & $\sqrt{ }$ & $\sqrt{ }$ & $\sqrt{ }$ & $\sqrt{ }$ & 8 \\
\hline & Pleurosigma & $\sqrt{ }$ & $\sqrt{ }$ & $\sqrt{ }$ & $\sqrt{ }$ & $\sqrt{ }$ & $\sqrt{ }$ & & & $\sqrt{ }$ & 8 \\
\hline & Rhabdonema & $\sqrt{ }$ & $\sqrt{ }$ & & & & & & & $\sqrt{ }$ & 3 \\
\hline & Rhizosolenia & $\sqrt{ }$ & $\sqrt{ }$ & & & & $\sqrt{ }$ & $\sqrt{ }$ & & & 4 \\
\hline & Skeletonema & & & & & & & & & & - \\
\hline & Streptotheca & & & & & & & & & & - \\
\hline & Surirella & & & & & & & & & & - \\
\hline & Thalassionema & & & & & & & & & & - \\
\hline & Thalassiothrix & $\sqrt{ }$ & & & & & & & & & 2 \\
\hline & Thalassiosira & & & & & & & & & & - \\
\hline & Ceratium & & & & & & & & & & - \\
\hline \multirow[t]{2}{*}{ Dinophyceae } & Dinophysis & $\sqrt{ }$ & $\sqrt{ }$ & & & & & & & & 2 \\
\hline & Peridinium & $\sqrt{ }$ & & & & & $\sqrt{ }$ & & & & 3 \\
\hline Cyanophyceae & Trichodesmium & & & & & & & & & & 1 \\
\hline Chrysophyceae & Dictyocha & & & & & & & & & & - \\
\hline$\Sigma$ & & 12 & 10 & 2 & 1 & 1 & 6 & 3 & 2 & 7 & \\
\hline
\end{tabular}

Keterangan:

Ikan 1 = Chelon subviridis/belanak jabu (Ghiffari 2017)

Ikan 2 = Moolgarda engeli/belanak kanda (Ghiffari 2017)

Ikan $3=$ Thryssa mystax/teri (Siregar 2017)

Ikan $4=$ Stolephorus indicus/teri (Siregar 2017)

Ikan 5 = Thryssa hamiltonii/teri (Siregar 2017)

Ikan $6=$ Sardinella gibbosa/tembang (Bukit 2017)

Ikan 7 = Anadontostoma chacunda/selanget (Bukit 2017)

Ikan $8=$ Sardinella fimbriata/tembang (Karina Bukit 2017)

Ikan $9=$ Parapocryptes serperaster/janjan (Khoncara 2017) 


\section{PEMBAHASAN}

Fitoplankton di Teluk Pabean didominasi oleh Bacillariophyceae dengan persentase sebesar 96,28\%. Fitoplankton kelas Bacillariophyceae (Diatom) merupakan salah satu fitoplankton yang mendominasi semua jenis fitoplankton di seluruh dunia (Nybakken 1997). Penelitian kelimpahan dan sebaran fitoplankton yang dilakukan oleh Damar (2003), Yuliana (2012), dan Wulandari (2014) juga menunjukkan fitoplankton kelas Bacillariophyceae (Diatom) yang paling dominan. Bacillariophyceae me-rupakan jenis fitoplankton yang paling toleran dan mampu beradaptasi dengan baik pada lingkungan perairannya, selain itu Bacillariophyceae memiliki kemampuan reproduksi yang lebih besar dibandingkan dengan fitoplankton kelompok lainnya (Nurfadillah $d k k$. 2012).

Kelimpahan fitoplankton kelas Bacillariophyceae, Dinophyceae, Cyanophyceae, dan Chrysophyceae pada setiap zona tidak berbeda secara signifikan. Hal tersebut diduga karena masukan cahaya yang diterima pada ketiga zona sama pada setiap penga-matan. Indonesia merupakan negara tropis yang umumnya cahaya yang diterima relatif sama pada setiap daerah. Secara signifikan kelimpahan fitoplankton kelas Bacillariophyceae dan Dinophyceae serta kelimpahan fitoplankton secara keseluruhan berbeda nyata pada setiap waktu pengamatan. Waktu pengamatan tidak berpengaruh secara signifikan terhadap kelimpahan fitoplankton kelas Cyanophyceae dan Chrysophyceae. Hal tersebut dikarenakan fitoplankton kelas Cyanophyceae hanya ditemukan pada empat bulan dan kelas Chrysophyceae tiga bulan dari total sepuluh bulan waktu pengamatan. Selain itu kelimpahan fitoplankton kelas Cyanophyceae dan Chrysophyceae secara statistik memiliki nilai rendah selama pengamatan, sehingga waktu pengamatan tidak berpengaruh terhadap kelimpahan kedua fitoplankton tersebut.

Analisis ragam keenam parameter fisik-kimiawi perairan (kedalaman, kecerahan, suhu, oksigen terlarut, salinitas, dan $\mathrm{pH}$ ) di Teluk Pabean menunjukkan perbedaan yang signifikan terhadap waktu pengamatan untuk parameter oksigen terlarut, salinitas dan $\mathrm{pH}$. Hal tersebut dikarenakan musim sangat memengaruhi nilai parameter tersebut, terutama oksigen terlarut, salinitas, dan $\mathrm{pH}$. Hasil pengamatan menunjukkan parameter fisik-kimiawi perairan tersebut masih sesuai untuk pertumbuhan fitoplankton di Teluk Pabean.

Kelimpahan fitoplankton tertinggi di perairan Teluk Pabean ditemukan pada bulan November 2016. Hal terse-but dikarenakan pada bulan November 2016 kecerahan perairan paling tinggi dibandingkan dengan bulan lainnya (Tabel 3). Ketika kecerahan tinggi maka intensitas cahaya yang masuk ke perairan juga akan tinggi sehingga akan meningkatkan fosintesis. Hubungan antara produktivitas primer dengan intensitas cahaya memiliki korelasi yang erat (Alianto $d k k$. 2008). Selain itu, nilai oksigen terlarut paling tinggi juga ditemukan pada bulan tersebut. Tingginya nilai oksigen terlarut karena terjadinya proses fotosintesis pada siang hari oleh fitoplankton (Simanjuntak 2009).

Fitoplankton mempunyai peran penting dalam rantai makanan di perairan karena mampu mengubah bahan anorganik menjadi bahan organik melalui proses fotosintesis. Bahan organik dari fitoplankton tersebut dimanfaatkan oleh zooplankton maupun ikan di perairan sebagai sumber makanan, sehingga kelimpahan fitoplankton menjadi penting bagi potensi sumber makanan ikan di alam. Beberapa ikan yang diteliti dan beberapa diantaranya pemakan fitoplankton adalah ikan famili Mugilidae, famili Engraulidae, famili Clupeidae, dan famili Gobiidae. Ikan-ikan tersebut merupakan konsumen pertama dengan memanfaatkan fitoplankton sebagai makanannya serta berfungsi sebagai penghubung antara produsen dengan konsumen yang lebih tinggi dalam trofik makanan. 
Ikan famili Mugilidae, famili Engraulidae, famili Clupeidae, dan famili Gobiidae tidak hanya memanfaatkan fitoplankton sebagai makanannya. Selain memakan fitoplankton, ikan famili Mugilidae juga memanfaatkan organisme dasar, makroalgae, plankton, dan bahan organik lainnya seperti FPOM (Fine Particulate Organic Matter) atau bahan organik halus dan CPOM (Coarse Particulate Organic Matter) atau bahan organik kasar (Isangedighi $d k k$. 2009). Ikan famili Clupeidae selain memakan fitoplankton juga memakan zooplankton. Simbolon $d k k$. (2010) menyatakan bahwa ikan teri (Stolephorus spp.) dari famili Engraulidae memangsa zoo-plankton sebagai makanan utamanya sebesar (94\%) sedangkan fitoplankton hanya 6\%.

Tidak semua jenis fitoplankton yang ditemukan dimakan oleh sembilan jenis ikan tersebut. Jenis Nitzschia dan Pleurosigma dari kelas Bacillariophyceae merupakan jenis yang paling banyak dimakan oleh beberapa ikan yang disebut diatas. Nitzschia dan Pleurosigma merupakan jenis fito-plankton yang dimakan oleh delapan ikan dari total sembilan ikan yang tertangkap dan memakan fitoplankton di Teluk Pabean.

Jenis fitoplankton yang tidak dimakan oleh beberapa ikan yang ditangkap di Teluk Pabean ada 13 genera dari 29 genera fitoplankton yang ditemukan, yaitu 12 genera dari kelas Bacillariophyceae (Amphiprora, Bacteriastrum, Cerataulina, Eucampia, Ethmodiscus, Guinardia, Skeletonema, Streptotheca, Thalassionema, Thalassiosira, dan Ceratium) dan satu genera dari kelas Chrysophyceae (Dictyocha). Tetapi tidak menutupkemungkinan jenis fitoplankton tersebut dimakan oleh ikan lain dari banyak ikan yg ada di Teluk Pabean.

Ikan yang paling banyak memakan jenis fitoplankton yaitu ikan Chelon subviridis dari famili Mugilidae. Ikan Chelon subviridis memakan 12 jenis fitoplankton dari 29 genera yang ditemukan. Hal tersebut berbeda dengan ikan Stolephorus indicus dan ikan Thryssa hamiltonii yang hanya mema- kan satu genera fitoplankton dari total 29 genera yang ditemukan di Teluk Pabean selama sepuluh bulan penga-matan. Hal tersebut dikarenakan ikan Stolephorus indicus dan ikan Thryssa hamiltonii merupakan ikan famili Engraulidae yang sebagian besar menyaring zooplankton sebagai maka-nannya, sehingga kedua ikan tersebut lebih banyak memakan zooplankton dibandingkan dengan fitoplankton.

\section{KESIMPULAN}

Kelimpahan fitoplankton tidak berbeda pada setiap zona, tetapi berbeda antar waktu pengamatan. Fitoplankton yang ditemukan di Teluk Pabean didominasi oleh kelas Bacillariophyceae. Jenis fitoplankton yang banyak dimanfaatkan oleh ikan-ikan di perairan Teluk Pabean adalah Nitzschia dan Pleurosigma.

\section{DAFTAR PUSTAKA}

Alianto, Adiwilaga EM, Damar A. 2008. Produktivitas primer fitoplankton dan keterkaitan-nya dengan unsur hara dan cahaya di perairan Teluk Banten. Jurnal Ilmu-ilmu Perairan dan Perikanan Indonesia, 15(1): $21-$ 26.

APHA. 2012. Standard Methods for the Examination of Water and Waste Water 22nd Edition. Ohio, AWWA; WEA. $1496 \mathrm{p}$.

Bukit STA. 2017. Ekologi trofik ikan famili Clupeidae di Teluk Pabean, Indramayu. Prosiding Masyarakat Iktiologi Indonesia. inprocess.

Chihara M, Murano M. 1997. An Illustrated Guide to Marine Plankton in Japan. Tokyo, Tokai University Press. 1547 p.

Damar A. 2003. Effects of enrich-ment on nutrient dynamics, phyto- 
plankton dynamics and productivity in Indonesian tropical waters: a comparison between Jakarta Bay, Lam-pung Bay and Semangka Bay. Berichte aus dem Forschungs-und Tecnologiezentrum Weskute der Universitat Kiel. Busun. 249 p.

Davis. 1955. The Marine and FreshWater Plankton. Hiroshima, Michigan State University Press. $562 \mathrm{p}$.

Effendi H. 2003. Telaah Kualitas Air: Bagi Pengelolaan Sumber Daya dan Lingku-ngan Perairan. Yogyakarta, Kanisius. 244 p.

Ghiffary GADA. 2017. Ekologi trofik ikan belanak (Famili: Mugilidae) di Teluk Pabean, Jawa Barat. Jurnal Iktiologi Indonesia. inprocess.

Isangedighi IA, Udo PJ, Ekpo IE. 2009. Diet composition of Mugil cephalus (pisces: mu-gilidae) in the cross river estuary, Niger Delta, Nigeria. Nigerian Journal of Agri-culture, Food, and Environment, 5(2-4): 10-15.

Khoncara AC. 2017. Ekologi trofik ikan famili Gobidae di Teluk Pabean, Indramayu. Prosiding Masyarakat Iktiologi Indonesia. inprocess.

Nontji. 2008. Plankton Laut. Jakarta, Lembaga Ilmu Pengetahuan Indonesia. $331 \mathrm{p}$.

Nurfadillah, Damar, Adiwilaga. 2012. Komunitas fitoplankton di perairan Danau Laut Tawar Kabupaten Aceh Tengah, Provinsi Aceh. Depik,1(2): 93-98.

Nybakken JW. 1997. Marine Biology: An Ecological App-roach. 4 ed. California, Addison-Wesley Educational Publishers Inc. 579 p.
Simanjuntak M. 2009. Hubungan faktor lingkungan kimia, fisika terhadap distribusi plankton di perairan Belitung Timur, Bangka Belitung. Jurnal Perikanan, 11(1): 31-45.

Simbolon D, Sondita MFA, Amiruddin. 2010. Komposisi isi saluran pencernaan ikan teri (Stolephorus spp.) di perairan Barru, Selat Makas-sar. Jurnal Ilmu Kelautan. 15(1): 7-16.

Wulandari DY, Pratiwi NTM, Adiwilaga EM. 2014. Distribusi spasial fito-plankton di perairan pesisir Tangerang (Spatial distri-bution of phytoplankton in the coast of Tangerang). Jurnal Ilmu Pertanian Indonesia (JIPI), 19(3): 156-162.

Yamaji I. 1979. Illustrations of the Marine Plankton of Japan. Japan, Hoikusha Publishing Co Ltd. 537 p.

Yuliana, Adiwilaga EM, Harris E, Pratiwi NTM. 2012. Hubu-ngan antara kelimpahan fitoplankton dengan parameter fisik-kimia perairan di Teluk Jakarta. Jurnal Akuatika, 3(2): 169-79. 
